\title{
Analisis Peranan Sumber Daya Manusia Dalam Pencapaian Kinerja Perusahaan pada PT. Perusahaan Perdagangan Indonesia (Persero) Regional Medan
}

\section{The Analysis of the Role of Human Resources in Achieving Company Performance at P.T. Perusahaan Perdagangan Indonesia Regional Medan}

\author{
Aswardi1),Yusniar Lubis' ${ }^{2}$, Syaifuddin Lubis ${ }^{3)}$ \\ 1)Program Studi Magister Agribisnis, Pascasarjana, Universitas Medan Area, Indonesia \\ 2)Magister Agribisnis, Pascasarjan, Universitas Medan Area, Indonesia \\ 3)Fakultas Ekonomi, Universitas Quality
}

\begin{abstract}
Abstrak
Penelitian ini bertujuan untuk mengetahui dan menganalisis peranan sumber daya manusia (karakteristik individu, kualitas, dan kompetensi karyawan) terhadap kinerja perusahaan pada PT. Perusahaan Perdagangan Indonesia (Persero) Regional Medan. Metode penelitian ini menggunakan pendekatan kuantitatif, jenis penelitiannya adalah survey. Sampel ditentukan dengan metode simple random sampling sebanyak 51 orang. Pengumpulan data dilakukan dengan kuesioner. Data dianalisis dengan menggunakan regresi linier berganda. Hasil penelitian menunjukkan bahwa secara simultan, variabel karakteristik individu, kualitas karyawan dan kompetensi karyawan berpengaruh positif dan signifikan terhadap kinerja perusahaan PT Perusahaan Perdagangan Indonesia (Persero) Regional Medan. Nilai koefisien determinasi sebesar 0,616 berarti bahwa pengaruh dari karakteristik individu, kualitas karyawan dan kompetensi karyawan terhadap perubahan kinerja perusahaan PT Perusahaan Perdagangan Indonesia (Persero) Regional Medan adalah sebesar 61,6\%.Secara parsial, terdapat pengaruh positif dan signifikan dari variabel kualitas karyawan dan kompetensi karyawan terhadap kinerja perusahaan PT Perusahaan Perdagangan Indonesia (Persero) Regional Medan. Sedangkan variabel karakteristik karyawan berpengaruh tidak signifikan terhadap kinerja perusahaan PT Perusahaan Perdagangan Indonesia (Persero) Regional Medan.

Kata kunci: $\quad$ Karakteristik Individu, Kualitas, Kompetensi Karyawan, Kinerja Karyawan
\end{abstract}

\begin{abstract}
The aims of study to identify and analyze the role of human resources (individual characteristics, quality, and employee competence) on the company's performance at Indonesia Trading Company of Medan Regional. This research using a quantitative approach with survey on the type of research. The sample was determined by simple random sampling method, 51 people. The data collection through questionnaires. Data were analyzed using multiple linear regression. The research results shows that simultaneously, the variable of individual characteristics, employee quality and employee competence have a positive and significantly effect to the performance at Indonesia Trading Company of Medan Regional. The determination coefficient value of 0.616 indicates that the influence of individual characteristics, employee quality and employee competence on the change of company performance at Indonesia Trading Company of Medan Regional is 61.6\%. Partially, there are positive and significantly influence of employee quality and employee competence to company performance at Indonesia Trading Company of Medan Regional. While the variable of employee characteristic have a non significantly effect to company performance Indonesia Trading Company of Medan Regional.

Keywords: $\quad$ Individual Characteristics, Quality, Employee Competence, Employee Performance.
\end{abstract}

How to Cite: Aswardi, Y. Lubis dan S. Lubis. (2019). Analisis Peranan Sumber Daya Manusia Dalam Pencapaian Kinerja Perusahaan pada PT. Perusahaan Perdagangan Indonesia (Persero) Regional

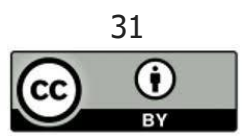


Aswardi, Y. Lubis dan S. Lubis, Analisis Peranan Sumber Daya Manusia Dalam Pencapaian Kinerja Perusahaan pada PT. Perusahaan Perdagangan Indonesia (Persero) Regional Medan

Medan. Jurnal Ilmiah Magister Agribisnis, 1(1) 2019: 31-39,

*E-mail: Yusniar@uma.ac.id

ISSN 2550-1305 (Online)

\section{PENDAHULUAN}

Persaingan dunia usaha yang semakin kompleks dan krisis ekonomi yang terjadi merupakan dua sisi permasalahan yang dihadapi perusahaan dalam upaya mempertahankan dan meningkatkan kinerja. Kemampuan perusahaan untuk bertahan dalam menghadapi permasalahan tersebut sangat tergantung pada sumber daya yang dimiliki perusahaan, baik keuangan, manusia dan teknologi. Sumber daya yang dimiliki dan dibutuhkan perusahaan tidak dapat dilihat sebagai hal yang berdiri sendiri, tapi harus dilihat sebagai satu kesatuan yang tangguh membentuk suatu sinergi. Dalam hal ini, peran sumber daya manusia (SDM) sangat menentukan, karena SDM merupakan satu-satunya sumber daya yang memiliki akal perasaan, keinginan, keterampilan, pengetahuan, dorongan, daya, dan karya.

Kegagalan perusahaan dalam mengelola SDM dapat mengakibatkan timbulnya gangguan dalam pencapaian tujuan perusahaan, baik dalam kinerja, profit, maupun kelangsungan hidup perusahaan itu sendiri. SDM merupakan sumber daya perusahaan yang sangat penting dan sentral, karena SDM-lah yang mengelola sumber daya keuangan dan juga operasional dari sumber daya teknologi yang dimiliki perusahaan.

Perhatian terhadap SDM dalam perusahaan memegang peran peting karena setiap karyawan memiliki karakteristik yang berbeda, sehingga manajemen harus dapat mengkombinasi semua perbedaan tersebut menjadi suatu kekuatan yang dapat digunakan mencapai tujuan perusahaan. Karakteristik individu ditunjukkan dari kemampuan, nilai/perilaku, sikap, dan minat (Robbins, 2003; As'ad, 2004). Karyawan dengan kemampuan kerja yang tinggi yang didukung oleh nilai perilaku dan sikap yang baik, serta minat kerja yang tinggi akan menjadikan seorang karyawan mampu melakukan pekerjaan dengan seoptimal mungkin untuk mendukung pencapaian kinerja perusahaan.

Karyawan yang diterima bekerja di suatu perusahaan juga harus memenuhi kualifikasi tertentu sesuai dengan kebutuhan perusahaan. Kualifikasi tersebut berhubungan dengan kualitas SDM yang dibutuhkan perusahaan, dengan pertimbangan bahwa semakin baik atau semakin tinggi kualitas SDM yang ada di perusahaan, maka SDM juga akan semakin mampu melakukan pekerjaan seoptimal mungkin. Oleh karena itu, perusahaan juga berusaha untuk meningkatkan kualitas SDM yang dimilikinya melalui pendidikan dan pelatihan, yang pada umumnya dilakukan secara berkala dan berkesinambungan. Pelaksanaan pendidikan dan pelatihan juga bertujuan agar SDM perusahaan dapat mengikuti perkembangan teknologi dan informasi yang ada. Penguasaan teknologi serta informasi, khususnya yang berkaitan dengan bidang usaha akan meningkatkan kemampuan SDM perusahaan, yang sekaligus juga meingkatkan kualitas SDM perusahaan tersebut.

Dalam menghadapi persaingan dunia usaha saat ini, salah satu hal yang perlu menjadi perhatian dan sekaligus menunjukkan kemampuan bersaing karyawan dalam suatu perusahaan adalah kompetensi. Kompentensi seorang individu merupakan sesuatu yang melekat dalam dirinya yang dapat digunakan untuk memprediksi tingkat kinerjanya. Sesuatu yang dimaksud bisa menyangkut motif, konsep diri, sifat, pengetahuan maupun keahlian (Mitrani, 1995). Kompentensi individu yang berupa keahlian dan pengetahuan bisa dikembangkan melalui pendidikan dan pelatihan. 
PT Perusahaan Perdagangan Indonesia (Persero), disingkat PT PPI yang dikenal juga sebagai ITC singkatan dari Indonesia Trading Company merupakan satu-satunya BUMN trading company di Indonesia. PT PPI bergerak di perdagangan umum meliputi ekspor, impor, dan distribusi yang merupakan merger dari tiga BUMN Niaga yaitu PT. Tjipta Niaga (Persero), PT. Dharma Niaga (Persero) dan PT. Pantja Niaga (Persero) yang berlaku efektif sejak tanggal 31 Maret tahun 2003 berdasarkan Peraturan Pemerintah Republik Indonesia No. 22 tahun 2003. PT PPI Regional Medan terdiri dari empat cabang, yaitu: Cabang Medan, Pekanbaru, Aceh dan Padang. Setiap cabang dibebankan target pendapatan yang harus dicapai dalam satu tahun. Pencapaian target tersebut merupakan salah satu indikator kinerja dari cabang dan selanjutnya pencapaian target dari cabangcabang tersebut akan menunjukkan kinerja dari Regional. Pecapaian target PT PPI Regional Medan pada tahun 2016 dapat dilihat pada tabel berikut.

Tabel 1. Rencana dan Realisasi Pendapatan PT. PPI (Persero) Regional Medan Tahun 2016

\begin{tabular}{lclcc}
\hline \multirow{2}{*}{ Cabang } & Jumlah & \multicolumn{2}{l}{ Pendapatan (Milyar Rp) } & $\%$ \\
& Karyawan (orang) & Rencana & Realisasi & Realisasi \\
\hline Medan & 20 & 160 & 152,0 & 95,0 \\
Pekanbaru & 16 & 60 & 60,0 & 100,0 \\
Aceh & 13 & 70 & 71,4 & 102,0 \\
Padang & 13 & 40 & 42,0 & 105,0 \\
Jumlah & 62 & 330 & 325,4 & 98,6 \\
\hline
\end{tabular}

Sumber: PT. PPI (Persero) Regional Medan, 2017.

Berdasarkan realisasi pendapatan tersebut, diketahui bahwa Cabang Medan tidak mencapai target, atau pencapaian hanya 95\% dari target, yang berarti juga bahwa kinerja dari Cabang Medan belum optimal. Sedangkan cabang-cabang lain, sudah mencapai target, dan ada yang melebihi. Secara keseluruhan di Regional Medan, bahwa pencapaian target mencapai 98,6\% yang berarti juga belum optimal. Pencapaian target yang belum optimal ini diduga berhubungan dengan SDM yang dimiliki perusahaan, karena pencapaian target tersebut adalah sebagai hasil kerja dari karyawan pada masing-masing cabang. Dengan jumlah karyawan yang terbatas, karyawan harus memiliki kualitas dan kompetensi sehingga dapat mencapai kinerja secara optimal, yang pada akhirnya juga akan mampu menghadapi persaingan dunia bisnis yang semakin ketat.

Sehubungan dengan permasalahan tersebut, maka dilakukan suatu kajian ilmiah dengan judul: Analisis Peranan Sumber Daya Manusia Dalam Pencapaian Kinerja Perusahaan pada PT. Perusahaan Perdagangan Indonesia (Persero) Regional Medan. Dalam penelitian ini, faktor sumber daya manusia yang dikaji adalah karakteristik individu, kualitas, dan kompetensi karyawan

\section{METODE PENELITIAN}

Penelitian dilakukan di PT. PPI (Persero) Regional Medan, yang dipilih secara sengaja (purposive).Bentuk penelitian ini adalah penelitian deskriptif kuantitatif dengan metode survey dan pengamatan di lapangan. Populasi dalam penelitian ini adalah seluruh karyawan di PT. PPI (Persero) Regional Medan sebanyak 62 orang. Sampel dalam penelitian ini adalah sebanyak 51 orang. Pengumpulan data dilakukan melalui kuesioner.Variabel diukur dengan skala Ordinal (1-5). 
Variabel independen pada penelitian ini adalah karakteristik individu, kualitas karyawan, kompetensi karyawan, sedangkan variabel dependen adalah kinerja perusahaan. Berikut persamaan regresi yang akan dianalisis :

$$
\begin{aligned}
& Y=\alpha_{0}+\alpha_{1} X_{1}+\alpha_{2} X_{2}+\alpha_{3} X_{3} \\
& \text { Keterangan : } \\
& Y=\text { kinerja perusahaan } \\
& \alpha_{0}=\text { konstanta } \\
& \alpha_{1,2,3}=\text { koefisien regresi } \\
& X_{1}=\text { karakteristik individu } \\
& X_{2}=\text { kualitas karyawan } \\
& X_{3}=\text { kompetensi karyawan }
\end{aligned}
$$

Pengujian hipotesis digunakan analisis regresi linier berganda, kemudian dilajutkan dengan uji $\mathrm{F}$ dan uji t. Uji $\mathrm{F}$ digunakan untuk analisis secara serempak, dengan ketentuan jika $\mathrm{F}_{\text {hitung }}>\mathrm{F}_{\text {tabel }}$ maka $\mathrm{H}_{0}$ ditolak dan $\mathrm{H}_{1}$ diterima, sebaliknya apabila $\mathrm{F}_{\text {hitung }} \leq \mathrm{F}_{\text {tabel }}$ maka $\mathrm{H}_{0}$ diterima dan $\mathrm{H}_{1}$ ditolak. Uji t digunakan untuk analisis secara parsial, dengan ketentuan jika $t_{\text {hitung }}>\mathrm{t}_{\text {tabel }}$ maka $\mathrm{H}_{0}$ ditolak dan $\mathrm{H}_{1}$ diterima, sebaliknya apabila $t_{\text {hitung }} \leq$ $\mathrm{t}_{\text {tabel }}$ maka $\mathrm{H}_{0}$ diterima dan $\mathrm{H}_{1}$ ditolak.

\section{HASIL PENELITIAN DAN PEMBAHASAN}

Berdasarkan analisis deskriptif diperoleh gambaran kondisi masing-masing variable berdasarkan jawaban responden, sebagaimana dilihat pada Tabel 1.

Tabel 1. Kondisi Variabel Penelitian

\begin{tabular}{llll}
\hline No. & Variabel & Skor & Kriteria \\
\hline 1. & Karakteristik individu & 4,08 & Baik \\
2. & Kualitas karyawan & 4,10 & Baik \\
3. & Kompetensi karyawan & 4,13 & Baik \\
4. & Kinerja perusahaan & 3,83 & Baik \\
\hline
\end{tabular}

Sumber : Data primer (diolah), 2017

Dengan demikian, kondisi masing-masing variabel yang diamati pada perusahaan tergolong baik. Pengaruh variabel karakteristik individu, kualitas karyawan dan kompetensi karyawan terhadap variabel kinerja perusahaandapat dilihat pada Tabel 2.

Tabel 2. Hasil Uji Serempak

\begin{tabular}{lllllll}
\multicolumn{2}{c}{ ANOVA $^{\mathrm{b}}$} & \multicolumn{2}{c}{ Sum } & of & & \\
\hline \multirow{2}{*}{ Model } & & Squares & $d f$ & Mean Square & $F$ & Sig. \\
\hline 1 & Regression & 1648.014 & 3 & 549.338 & 25.104 & $.000^{\text {a }}$ \\
& Residual & 1028.496 & 47 & 21.883 & & \\
& Total & 2676.510 & 50 & & & \\
\hline
\end{tabular}

a. Predictors: (Constant), X3, X2, X1

b. Dependent Variable: $Y$

Sumber: Data primer (diolah), 2017

Dari Tabel 2 diketahui nilai $\mathrm{F}_{\text {hitung }}$ sebesar 25,104. Dengan menggunakan confidence interval (CI) $95 \%$ df 3:47 ( $\alpha=0.05)$ maka dari tabel distribusi $\mathrm{F}$ diperoleh nilai 2,8. 
Dengan demikian $\mathrm{F}_{\text {hitung }} 25,104>\mathrm{F}_{\text {tabel }} 2,8$ maka $\mathrm{H}_{0}$ ditolak dan $\mathrm{H}_{1}$ diterima, artinya variabel karakteristik individu, kualitas karyawan dan kompetensi karyawanberpengaruh signifikan terhadap variabel kinerja perusahaan pada PT. PPI (Persero) Regional Medan.

Nilai koefisien determinasi $\left(\mathrm{R}^{2}\right)$ diketahui besarnya pengaruh perubahan variabel karakteristik individu, kualitas karyawan dan kompetensi karyawan terhadap perubahan variabel kinerja perusahaan pada PT. PPI (Persero) Regional Medan, disajikan pada Tabel 3.

Tabel 3. Koefisien Determinasi

Model Summary

\begin{tabular}{lllll}
\hline Model & $R$ & R Square & Adjusted R Square & Std. Error of the Estimate \\
\hline 1 & $.785^{\mathrm{a}}$ & .616 & .591 & 4.67792 \\
\hline
\end{tabular}

a. Predictors: (Constant), $X 3, X 2, X 1$

Sumber: Data primer (diolah), 2017

Nilai koefisien determinasi sebesar 0,616 berarti bahwa perubahan kinerja perusahaan pada PT. PPI (Persero) Regional Medan dapat dijelaskan oleh perubahan karakteristik individu, kualitas karyawan dan kompetensi karyawan sebesar 61,6\%. Sedangkan sisanya sebesar $38,4 \%$ dipengaruhi oleh variable lain yang tidak dianalisis dalam penelitian ini.

Uji pengaruh variabel karakteristik individu, kualitas karyawan dan kompetensi karyawan secara parsial dapat dilihat pada Tabel 4.

Tabel 4. Hasil Uji Parsial

\begin{tabular}{|c|c|c|c|c|c|}
\hline & \multirow[b]{2}{*}{ Kodel } & \multicolumn{2}{|c|}{ Unstandardized Coefficients } & \multirow[b]{2}{*}{$\mathrm{t}$} & \\
\hline & & \multirow{2}{*}{\begin{tabular}{l}
\multicolumn{1}{|c}{ B } \\
4.059
\end{tabular}} & Std. Error & & Sig. \\
\hline 1 & (Constant) & & 6.258 & 649.520 & \\
\hline & $\mathrm{X} 1$ & .072 & .165 & .437 .664 & \\
\hline & $\mathrm{X} 2$ & .371 & .176 & 2.111 .040 & \\
\hline & X3 & .421 & .166 & 2.533 .015 & \\
\hline
\end{tabular}

Sumber: Data primer (diolah), 2017

Berdasarkan nilai koefisien regresi (B) hasil analisis, maka diperoleh persamaan regresi sebagai berikut:

$$
\mathrm{Y}=4,059+0,072 \mathrm{X}_{1}+0,371 \mathrm{X}_{2}+0,421 \mathrm{X}_{3}
$$

Dari Tabel 4 diperoleh diperoleh nilai thitung masing-masing variabel. Nilai $t_{\text {hitung }}$ tersebut selanjutnya dibandingkan dengan nilai $t_{\text {tabel }}$ pada tingkat kepercayaan $95 \%$ atau $\alpha=0,05$. Nilai tabel pada df 47 dengan $\alpha=0,05$ adalah 2,01. Pengaruh parsial dari variabel karakteristik individu (X1)diperoleh dengan nilai thitung sebesar 0,437, dengan demikian $t_{\text {hitung }}<t_{\text {tabel, }}$ maka $\mathrm{H}_{0}$ diterima, yang berarti bahwa karakteristik individuberpengaruh tidak signifikan terhadap kinerja perusahaan PT Perusahaan Perdagangan Indonesia (Persero) Regional Medan. Berdasarkan arahnya, dapat diketahui bahwa karakteristik individu bernilai positif, hal ini berarti bahwa apabila karakteristik individusemakin baik maka kinerja perusahaan PT Perusahaan Perdagangan Indonesia (Persero) Regional Medan juga akan meningkat.

Pengaruh parsial dari variabel kualitas karyawan $\left(\mathrm{X}_{2}\right)$ diperoleh dengan nilai $\mathrm{t}_{\mathrm{itung}}$ sebesar 2,111, dengan demikian $t_{\text {hitung }}>t_{\text {tabel, }}$ maka $\mathrm{H}_{0}$ ditolak dan $\mathrm{H}_{1}$ diterima, yang 
berarti bahwa variabel kualitas karyawan berpengaruh positif dan signifikan terhadap kinerja perusahaan PT Perusahaan Perdagangan Indonesia (Persero) Regional Medan. Hal ini berarti bahwa bila kualitas karyawansemakin baik maka kinerja perusahaan PT Perusahaan Perdagangan Indonesia (Persero) Regional Medan juga akan meningkat.

Pengaruh parsial dari variabel kompetensi karyawan $\left(\mathrm{X}_{3}\right)$ diperoleh dengan nilai $t_{\text {hitung }}$ sebesar 2,533, dengan demikian $t_{\text {hitung }}>t_{\text {tabel, }}$, maka $\mathrm{H}_{0}$ ditolak dan $\mathrm{H}_{1}$ diterima, yang berarti bahwa variabel kompetensi karyawan berpengaruh positif dan signifikan terhadap kinerja perusahaan PT Perusahaan Perdagangan Indonesia (Persero) Regional Medan. Hal ini berarti bahwa bila kompetensi karyawansemakin baik maka kinerja perusahaan PT Perusahaan Perdagangan Indonesia (Persero) Regional Medan juga akan meningkat.

Berdasarkan hasil analisis diketahui bahwa nilai koefisien regresi yang paling tinggi adalah variabel kompetensi karyawan $\left(\mathrm{X}_{3}\right)$. Hal ini berarti bahwa karakteristik individu berpengaruh lebih dominan terhadap kinerja perusahaan PT Perusahaan Perdagangan Indonesia (Persero) Regional Medan.

Hasil analisis menunjukkan bahwa secara simultan, variabel karakteristik individu, kualitas karyawan dan kompetensi karyawan berpengaruh signifikan terhadap kinerja perusahaan PT Perusahaan Perdagangan Indonesia (Persero) Regional Medan. Sedangkan secara parsial, variabel karakteristik individu berpangruh tidak signifikan terhadap kinerja perusahaan, tetapi ketiga variabel secara parsial berpengaruh positif terhadap kinerja perusahaan. Hasil penelitian menunjukkan bahwa sumber daya manusia berperan positif dan signifikan terhadap kinerja perusahaan PT Perusahaan Perdagangan Indonesia (Persero) Regional Medan. Oleh karena itu, salah satu upaya untuk meningkatkan kinerja perusahaan adalah dengan meningkatkan sumber daya manusia yang dimiliki, terutama melalui pelatihan. Hasil penelitian tersebut sejalan dengan penelitian Samir dan Larso (2011), bahwa kinerja UKM Catering di Kota Bandung dipengaruhi secara signifikan oleh manajemen sumber daya manusia.

Variabel karakteristik individu berpengaruh positif terhadap kinerja perusahaan, hal ini berarti bahwa salah satu upaya untuk meningkatkan kinerja perusahaan adalah dengan meningkatkan karakteristik individu karyawan. Hasil penelitian Supriyanto, Hamzah, dan Kadir (2013) menunjukkan bahwa karakteristik individu, berpengaruh signifikan terhadap kinerja karyawan, dan memiliki pengaruh yang lebih kuat terhadap kinerja karyawan dibandingkan karakteristik organisasi. Oleh karena itu bahwa faktor karakteristik individu dan karakteristik organisasi penting dipertimbangkan dalam menetapkan kebijakan pengembangan kinerja karyawan.

Variabel kualitas karyawan berpengaruh positif terhadap kinerja perusahaan, hal ini berarti bahwa salah satu upaya untuk meningkatkan kinerja perusahaan adalah dengan meningkatkan kualitas karyawan. Hasil penelitian ini sejalan dengan penelitian Sitohang (2010), Saharuddin dan Budiman (2014), dan Marwoto (2014), bahwa kualitas SDM berpengaruh signifikan terhadap kinerja pegawai.

Variabel kompetensi karyawan berpengaruh positif terhadap kinerja perusahaan, hal ini berarti bahwa salah satu upaya untuk meningkatkan kinerja perusahaan adalah dengan meningkatkan kompetensi karyawan. Hasil penelitian ini sejalan dengan Adriana, Brahmayanti dan Subaedi (2010), bahwa kompetensi SDM berpengaruh signifikan terhadap kinerja UKM di Surabaya. Dari tiga dimensi kompetensi SDM yang dianalisis, ketrampilan dan kemampuan memiliki pengaruh yang signifikan, sedangkan dimensi pengetahuan tidak berpengaruh signifikan. Oleh karena itu, variabel keterampilan dan kemampuan perlu diperhatikan dalam meningkatkan kinerja UKM. Hasil penelitian 
Supartha, dkk (2014) juga menyatakan bahwa kompetensi ketua Lembaga Perkreditan Desa (LPD) berpengaruh signifikan terhadap kinerja LPD.

\section{SIMPULAN}

Secara simultan, variabel karakteristik individu, kualitas karyawan dan kompetensi karyawan berpengaruh positif dan signifikan terhadap kinerja perusahaan PT Perusahaan Perdagangan Indonesia (Persero) Regional Medan. Nilai koefisien determinasi sebesar 0,616 berari bahwa pengaruh dari karakteristik individu, kualitas karyawan dan kompetensi karyawan terhadap perubahan kinerja perusahaan PT Perusahaan Perdagangan Indonesia (Persero) Regional Medan adalah sebesar 61,6\%. Secara parsial, terdapat pengaruh positif dan signifikan dari variabel kualitas karyawan dan kompetensi karyawan terhadap kinerja perusahaan PT Perusahaan Perdagangan Indonesia (Persero) Regional Medan. Sedangkan variabel karakteristik karyawan berpengaruh tidak signifikan terhadap kinerja perusahaan PT Perusahaan Perdagangan Indonesia (Persero) Regional Medan.

Karakteristik individu karyawan yang perlu mendapat perhatian adalah berkaitan dengan tekanan kerja, dimana sebagian karyawan tidak dapat bekerja di bawah tekanan sehingga perusahaan perlu melakukakan edukasi atau pengembangan sehingga karyawan-karyawan tersebut mampu bekerja sesuai harapan perusahaan. Kualitas karyawan yang perlu mendapat perhatian adalah penguasaan teknologi. Oleh karena itu, perusahaan perlu melakukan pelatihan kepada karyawan-karyawan tersebut sehingga dapat menguasai dan mengoperasikan teknologi yang digunakan dan yang akan digunakan oleh perusahaan dalam aktivitas bisnisnya. Dalam upaya meningkatkan kompetensi karyawan, perusahaan perlu memperhatikan kemampuan karyawan mengimplementasikan pengetahuan untuk mencapai tujuan perusahaan.

\section{DAFTAR PUSTAKA}

Ardiana; Brahmayanti, I.A, \& Subaedi. (2010). Kompetensi SDM dan Pengaruhnya Terhadap Kinerja UKM di Surabaya. Jurnal Manajemen dan Kewirausahaan. V(12).

As'ad, Mohammad. (2004). Kepemimpinan Efektif Dalam Perusahaan, Suatu Pendekatan Psikologik. Edisi Kedua. Yogyakarta: Liberty.

Marwoto, Nuki. (2012). Pengaruh Kualitas Sumber Daya Manusia (SDM), Komunikasi dan Komitmen Organisasi Terhadap kinerja Pegawai Satuan Perangkat Daerah (SKPD) Di Lingkungan Pemerintah Kabupaten Karimun. Tesis. Universitas Terbuka.

Mitrani, Alain. (1995). Manajemen Sumber Daya Manusia Berbasis Kompetensi (Terjemahan). Jakarta: PT. Intermasa.

Robbins, Stephen P. (2003). Perilaku Organisasi, Jakarta: PT. Indeks Kelompok Gramedia.

Saharuddin dan Budiman. (2014). Pengaruh Kualitas Sumber Daya Manusia Dalam Meningkatkan Kinerja Tim Pengelolah Kegiatan Program Nasional Pemberdayaan Masyarakat Mandiri Pedesaan (TPK PNPM-MP) PNPM-MP di Kecamatan Masamba Kabupaten Luwu Utara. Jurnal Manajemen Vol. 01 No. 02, Juli.

Samir, Alfin \& Larso, Dwi. (2011). Identifikasi Faktor-Faktor yang Mempengaruhi Kinerja UKM Catering di Kota Bandung. Jurnal Manajemen Teknologi Volume 10 Nomor 2.

Sitohang, Sonang (2010). Pengaruh Kualitas Sumber Daya Manusia Terhadap Kinerja Pengrajin Sentra Industri Kecil Tenun Ikat. Ekuitas Vol. 14 No. 1 Maret.

Supartha, Wayan Gede et al. (2014). Peran Mediasi Budaya Organisasi, pada Pengaruh Kompetensi dan Motivasi Ketua Lembaga Perkreditan Desa (LPD) Terhadap Kinerja LPD (Studi pada LPDdi Kabupaten Gianyar). Lapoaran Penelitian Program Studi Doktor Ilmu Manajemen Universitas Udayana, Denpasar.

Supriyanto, Sapto, Djabir Hamzah \& Abdul Rahman Kadir. (2013). Pengaruh Karakteristik Individu dan Karakteristik Organisasi Terhadap Motivasi Kerja dan Kinerja Karyawan Departemen Engineering Technical Development \& Support PT. Vale Indonesia Tbk, Magister Manajemen Universitas Hasanuddin, Makassar. 